regional programme service to the Midlands. The present aim of the British Broadcasting Corporation is to supply every potential listener with a service of two distinct programmes. The distribution scheme which is now approaching completion will make one programme available to 98 per cent of the population and the other programme available to 85 per cent. By virtue of the length of the wave on which it works, and its aerial power of 150 kilowatts, the new long-wave transmitter at Droitwich gives vastly greater possibilities of 'coverage' than any of the other transmitters in the country, all of which work on medium waves. The other Droitwich transmitter covers the densely populated districts in the Midlands. The Droitwich site was found to fulfil the requirements for a station of this type. The subsoil in the immediate neighbourhood is favourable to the propagation of radio waves. Short high-grade telephone circuits connect it with the nearest studio head. quarters. It is suitable for building work, and there is plenty of space for the aerial system. Lastly there is a trustworthy and ample water supply.

\section{Value of Criticism}

Prof. Erwin SchrödINGER, in an article entitled "Science, Art and Play" (Philosopher, 13, No. 1), maintains that the present-day spirit which challenges all authority and allows nothing to be immune from criticism, manifests itself in the 'crisis' now existing in most of the sciences. Science, at any rate research work, together with art and play, provides an outlet for that surplus store of energy which men usually have to spare after satisfying their primary needs. It might be argued that science gives far greater practical benefits than art or play, or that the intellectual joy of the research worker is as nothing to the material value of the results obtained. But the advances of applied science, as exemplified in greater facilities for travel and communication, give not only material benefits but also pleasure for their own sake. Prof. Schrödinger admits that science can rarely give direct joy to the community, but what matters is that the greatest possible number of people should have the opportunity of approach to intellectual pleasures. It is not accidental that at the present moment the sciences are being forced to a complete reassessment of values, for the ideas forming the background of the individual sciences are connected with the ideas of the age, and the dominant spirit will accept nothing on authority. This should not be feared, for what is worth preserving preserves itself, and requires no protection.

\section{The Citrus Industry in Jaffa}

AN article in the Fruit, Flower and Vegetable Trades' Journal of February 16 describes "The Jaffa Citrus Industry". Oranges were introduced to Jaffa in the tenth century; they delighted the eyes of the Crusaders and their opponents. An Egyptian devastated the town and the surrounding country in the fourteenth century, and the orange groves were not re-established until the eighteenth century. Palestine exported nearly $1 \frac{1}{2}$ million boxes of oranges before the War ; her export trade disappeared during the conflict, but now it has returned and increased. Jaffa is the chief exporter of grape fruit, and second only to Spain in export of oranges. Forty-five per cent of the exportable crop is at present controlled by Jews and the rest by Arabs, but when present plantings mature, the Jews will control 65 per cent. The development of overseas markets is difficult, owing to the imposition of tariffs, and to the fact that Palestine is a mandated territory and can demand no reciprocity of trade. The Government of Palestine has instituted an inspection service, has established a research station and has created a fund for propaganda. Difficulties of transport from Jaffa to the port have still to be overcome; production promises to be increased threefold by 1938. The industry is launching a large scheme of advertisement, in an attempt to cope with this increase in output, and already the consumption of Jaffa oranges in England has increased considerably since the scheme was initiated.

\section{Land Utilisation Survey}

THE fourth annual report, for 1934, of this Survey shows that great progress has been made. Of the field work, only about ten per cent of the total area of Great Britain has still to be done. The uncompleted areas are mainly in Sutherland, part of the Southern Uplands, the northern and eastem parts of the West Riding, central and southern Wales, and parts of Wiltshire and Cornwall. In preparation of the six-inch sheets for publication, which entails reduction to a one-inch scale, much progress has also been made. Twelve sheets have been published, seven others are in the press and twenty more have been reduced. Further progress has been delayed solely by lack of funds. For many of the sheets published or in process of publication grants, guarantees or advance orders have been obtained, and the Survey is anxious to obtain further help of this kind. The Survey is planning a series of handbooks to accompany the published sheets.

\section{Cultivation of Tomatoes}

THE imposition of duties on imported tomatoes has naturally stimulated the production of this fruit in Great Britain, although the industry had already assumed large proportions. The home production under glass is estimated at more than 1,140,000 cwt., but even so, this only accounts for less than one third of the total home consumption, imports for 1932 amounting to as much as $2,442,000$ cwt. Very considerable knowledge with regard to tomato growing has been obtained at the Cheshunt Research Station, and at the invitation of the Ministry of Agriculture, the director, Dr. Bewley, has prepared a bulletin on the subject which provides growers with a wealth of valuable information (Bull. No. 77, Tomatoes: Cultivation, Diseases and Pests. H.M. Stationery Office. $1 s .6 d$, net). Soil treatment before planting, manuring, optimum soil and air temperature during growth are among the aspects of the subject discussed in detail, while recommendations as to the 
choice of the best variety, methods of marketing and measures to be adopted for the control of diseases and pests are also supplied. In addition, the construction and heating of glasshouses are considered, and a detailed plan of a low-pressure hot water heating apparatus is appended.

\section{Cambridge Philosophical Society}

ThE Proceedings of the Cambridge Philosophical Society now appears in a new and more convenient form. The number of parts in a volume has been reduced from about seven to four, to be published at the ends of January, April, July and October, but the size of the page has been increased, and the general style and layout have been considerably modified so as to bring the journal more into line with the Proceedings of the Royal Society and the London Mathematical Society. The first issue in this new form contains papers by Prof. G. H. Hardy on "Fourier Kernels", Prof. G. N. Watson on "Ramanujan's Continued Fraction", and six other papers on pure mathematics. As for mathematical physies, M. H. L. Pryce applies Born's new field theory to a simple special case; A. Lees places a new interpretation on Dirac's linear wave equation; H. A. Bethe discusses the neutrino; and W. W. Sawyer deals with a point in the separation of heavy hydrogen. The experimental papers include experiments on neutrons by $\mathrm{C}$. H. Westcott and T. Bjerge, and investigations of downcoming wireless waves by J. L. Pawsey. We regret to notice that the Council has decided not to issue any more parts of the Transactions of the Society at present. In the past it has contained many researches which were of great value, but too lengthy for the Proceedings.

\section{Population Growth and Birth-Control}

RAPID increase of the population of India has led to a demand for the inception of preventive measures. Birth-control there, and also in Great Britain, is, however, eriticised by Col. C. A. Gill in a recent somewhat polemical paper (J. Hygiene, 34, 502; 1934). According to Col. Gill, population in an area ought to be considered not only from the point of view of numbers, but also from the occurrence of irregular changes or 'movements' in the population, which, apart from migration, are largely determined by forces controlling the birth- and death-rates. Statistical methods forecasting future population ignore such 'movements' of population, and estimates based upon population-growth curves have proved unreliable, for example, in India, and must be accepted with reserve. In a primitive community, prolificity as a means of race survival and an essential factor for progressive evolution is a paramount necessity, and artificial birth-control would constitute racial infanticide. Rural India, it is held, is such a community and is under-populated, and any State action to promote the practice of birth-control there is regarded as being a political crime and a biological blunder. In Great Britain, natural forces are now acting tending to limit increase of population, such as postponement of the average age of marriage and, possibly, a real decline in fertility. Since Nature requires a wide field of selection, nothing should be done to restrict the reservoir from which in the past many have sprung who have contributed greatly to human progress. The encouragement of birthcontrol among the masses, it is argued, is therefore to be regarded as being biologically reprehensible.

\section{The Geographical Magazine}

A NEW monthly publication has appeared entitled the Geographical Magazine (London: Geographical Magazine, Ltd., ls.). The first number fulfils the aim of the editor to depict the geographical background of important events, works of construction and conservation, and the conditions in which various peoples are living throughout the world. Attention will be given also to exploration, travel in littleknown lands and among primitive peoples, and the life of animals in relation to their environment. The eight articles include accounts of Abyssinia by Major R. E. Cheesman, India's North-East Frontier by Capt. Kingdon Ward, the routes in the North Syrian desert by Miss C. P. Grant, the aborigines of Central Australia by Mr. B. Macgraith, the "Changing Face of Amsterdam" by Mr. F. R. Yerbury. The home country is represented by an article on the Lake District by Mr. Hugh Walpole and Prof. P. Abercrombie. There are numerous and good illustrations and a small map is given with each article. Half the profits made by the magazine are to be devoted to a fund for the promotion of geographical knowledge to be administered by a body of trustees under the chairmanship of the president of the Royal Geographical Society.

\section{World Survey}

Published under the auspices of the World Power Conference, a new monthly periodical entitled World Survey has appeared this month (5s. net), its aim being described as that of presenting and analysing world economic trends. A special feature is the inclusion of a section recording, by means of index numbers, changes in industrial and agricultural production, wholesale and retail prices, unemployment, production of power and fuel and other statistics relating to transport, finance and world trade. In the first number, the articles cover a wide field, including among other subjects the future development of power-producing industries, the international aspects of public works, and machinery and labour displacement. In a special world economic service section, there are articles dealing with Belgium and the gold standard and with the world rubber situation. It is intended that World Survey shall facilitate an international exchange of information and opinion between those engaged in the power and fuel industries and economic experts, so that industrial data can be analysed and related continuously to theoretical work. An international bibliography of new publications relating to power and fuel is also included as a monthly feature. 